\title{
コンテナの耐風に関する模型実験一II
}

\author{
堀 \\ 富士男*
}

Model Experiments on the Effect of Wind upon Container - II.

\section{Fujio HORI}

\begin{abstract}
In order to investigate the wind-action containers, by making use of a wind generator closed-type, the author carried out the model test on a container and the simulation of stacked containers in the PC -11 Container Yard (Kobe Port Island). Models for getting the wind force coefficient are 1/20 scale of 20 feet dry container and simulation models are $1 / 40$ scale of 40 feet dry container.
\end{abstract}

The results of experiments were as follows:

(1) As compared with results of another methods, I could confirm the wind force coefficients.

(2) When the wind blows at right angles to the front surface of container $\left(\theta=0^{\circ}\right)$, these values are drag coefficient $\left(C_{d}\right)=1.025$, lift $\operatorname{coefficient}\left(C_{l}\right)=0.581$ respectively.

The result by the simulation tests showed that in the range of $\theta=15^{\circ}$ to $30^{\circ}$ stacked containers started to slide by lower wind velocity.

1. は じめに

コンテナ・ヤードに藏置された空コンテナの強風による飛散の間題について，先の報告(1) は，神戸商船大学の 開放型風洞において行ったものであるが，それ以後本校の密閉型風洞に扔いて，先の実験とは異なった方法によ って，主に風圧係数を求める基礎実験を行ってきた。その間に日本海上コンテナ協会もこの闆題を取り上げて報 告畫 ${ }^{(2)}$ が出された。これらの基礎実験の結果を比較検討することによって，風圧力係数を確認すると同時に，そ の結果をるとにして，神戸ポートアイランドの PC一11ヤードから資料の提供を載き，同ヤードをモデルにして， 縮尺 1/40 のコンテナ及びコンテナ・ヤードの模型を作製して，15度毎に全風向にわたるコンテナの滑動・転倒 の限界風速に関してシミュレーションを行い，それらの結果をあとめたものである。

\section{2. 実 験 方 法}

\section{1 供試模型}

本実験に使用したコンテナ模型は，風圧力測定用に 20 フィートドライコンテナ $(L \times B \times H \times W=6.06 \mathrm{~m}$ $\times 2.44 \mathrm{~m} \times 2.44 \mathrm{~m} \times 1.0$ ton $)$ の縮尺 $1 / 20$ のアクリル 板製模型（ $L \times B \times H \times W=0.30 \mathrm{~m} \times 0.12 \mathrm{~m} \times 0.12 \mathrm{~m} \times$ $0.213 \mathrm{~kg})$ と，シミュレーション用には 40 フィートドライコンテナ（ $L \times B \times H \times W=12.19 \mathrm{~m} \times 2.44 \mathrm{~m} \times 2.44 \mathrm{~m}$ $\times 3.0 \mathrm{ton})$ を基準にした縮尺 $1 / 40$ の塩化ビニール板製模型 $(L \times B \times H \times W=0.30 \mathrm{~m} \times 0.06 \mathrm{~m} \times 0.06 \mathrm{~m} \times 0.06 \mathrm{~kg})$ を多数作製しそれぞれにコーナーポストを取り付けた。シミュレーションは，3. $6 \mathrm{~m} \times 2.7 \mathrm{~m}$ の実験台上にP C一 11ヤードの $1 / 40$ 縮尺の建物模型を作製して上記供試模型を配置して行った。

\section{2 実験装置及び要領}

弓削商船高専の密閉式吸い込多型風洞装置（吹出し口 $6.6 \mathrm{~m} \times 0.5 \mathrm{~m} ，$ 最大風速 $8 \mathrm{~m} / \mathrm{sec}$ ) を使用し，風圧力測 定には定格負荷 $\left(F_{x} \times F_{y} \times F_{z}=1.0 \mathrm{~kg} \times 1.0 \mathrm{~kg} \times 0.4 \mathrm{~kg} \cdot \mathrm{m}\right)$ の三分力検力計を使用した。風速測定は熱線風速計 で直読すると同時にピト一管に小型差圧変換器を取り付けて，三分力と共にデータをマイコンで処理した。

* 正会員 弓削商船高等尃門学校（愛媛県越智郡弓削町下弓削） 
(1) 風生力測定

風圧力測定用模型は，縮尺 $1 / 20$ の 20 フィードライコンテ ナの 1 段，2段積み連結及び 3 段積み連結を用い，その内部の 長さ及び高さの中央に図 1 の様に三分力計を取り付けて，多ぺ ンレコーダーとマイコンに接続して， $F_{x}$ (揚力),$F_{y}$ (抗力) 及 び $F_{z}$ (モーメント) とピト一管の差圧を同時に読み取った。上 記の模型を風洞吹出しロ前面に設けた実験台上にセットして1 段積み，2段積み上段，2段積み連結， 3 段積み最上段及び 3

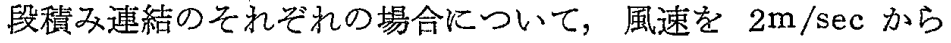

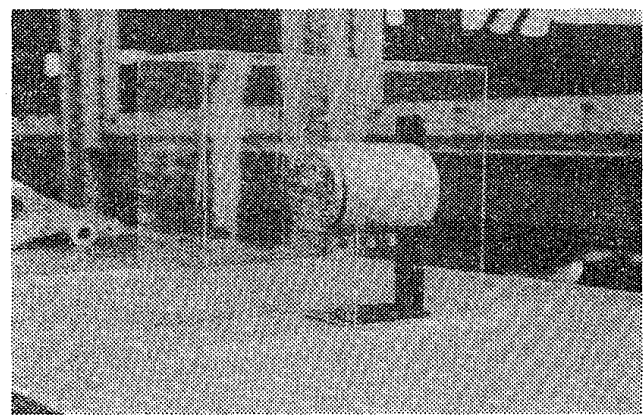

図 1 (写真) 風圧力測定模型

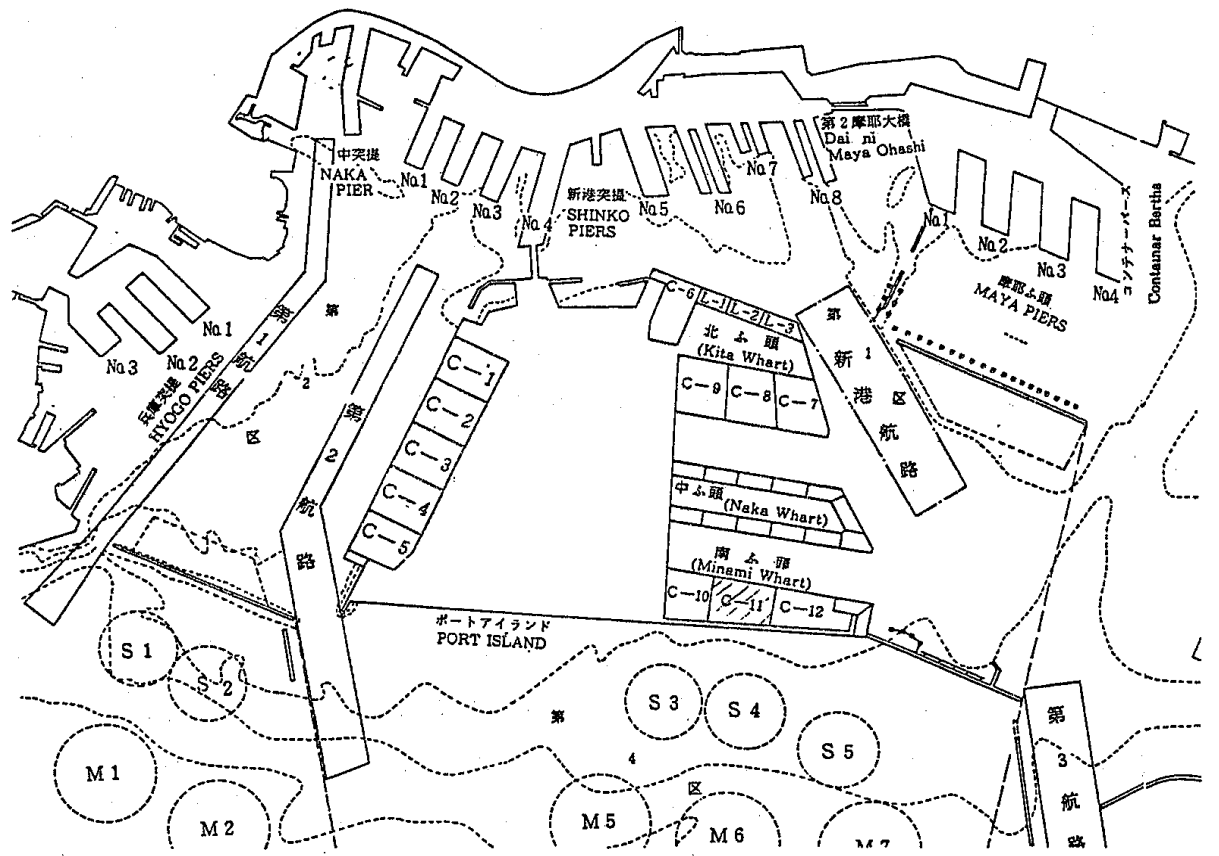

図 2 神戸港 $\mathrm{PC}-11$ ヤード

$6 \mathrm{~m} / \mathrm{sec}$ の範囲で 6 段階に変化させて風圧力を測定した。次に コンテナの受ける風の角度を長手方向に值角垱る風を $\theta=0^{\circ}$ として75度まで15度毎に変化させて 2 段階の風速で同様の笑験 を行った。

（2）ヤード模型奌験

図 2 に示す神戸港ポートアイランドの南埠頭C一11ヤードの 縮尺 $1 / 40$ の模型を作製して実験台に配列して，ヤード自体を 15度ずつ 360 度回転させて全方向からの風に対するコンテナの 挙動を観測した。その模様を図 3 に示す。P C-11ヤードは図

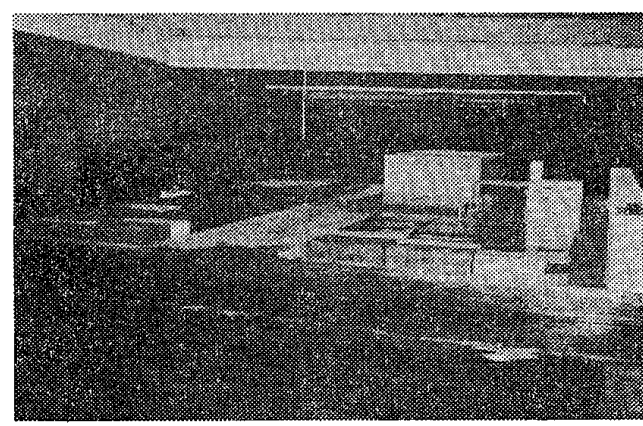

図 3 (写真) シミュレーション装置

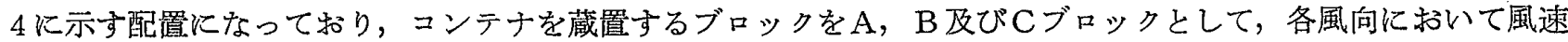
を徐々に増加させて，いずれのブロックでどの位置のコンテナが滑動を開始するか目視観測すると同時にビデオ に収録し，滑動した瞬間の風速を熱線風速計で測定した。実験は 1 段積みと 3 段積みフリーで行い，風速計の高 さは段積みの高さの中央にセットした。各ブロックのスタッキングエリアに実際の数のコンテナを配列すること は图難で，滑動するのは風に対して最前面のコンテナであることから，周辺には供試模型を配し中央部にはダミ ーとしてベニヤ板製のコンテナ模型を配した。 


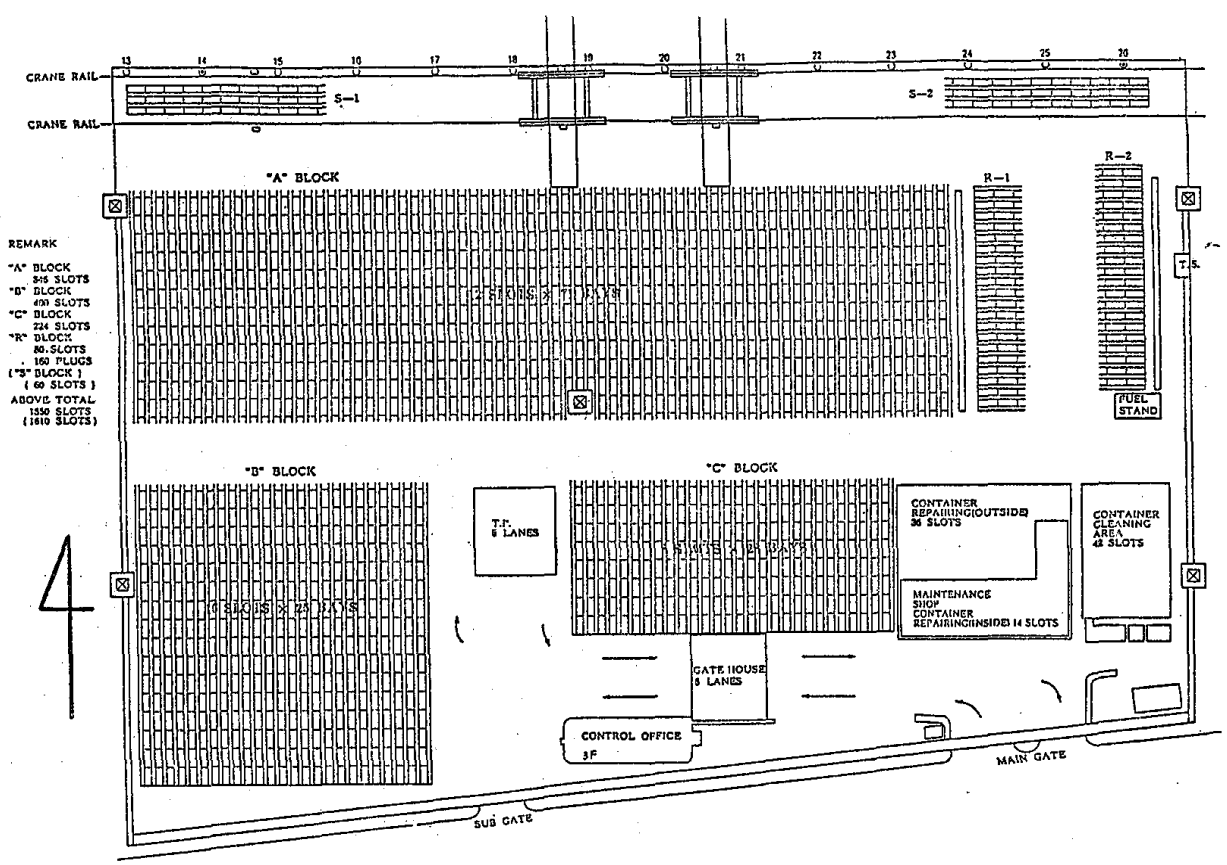

図 4 P C-11 - ド配置図

\section{3. 実験結果とその検討}

\section{1 風圧力測定}

風圧力を測定するに先立ち，風速の垂直分布を熱線風速計を 用いて測定しその結果を図 5 に示す。密閉型風洞のため天井と 実験台の両方で境界層が出来る。3 段積みの高さが縮尺 $1 / 20$ の模型で $36.6 \mathrm{~cm}$ であり，天井の影響が及ばないように可動式 底板を調節して天井と実験台までの高さを $70 \mathrm{~cm}$ とした。上下 の風速分布が対称でないのは，アクリル板の天并とべニヤの実 験台といらことと，風洞の吹出し口の高さが $50 \mathrm{~cm}$ で実験台上 にやや吹き下し気味であることが原因と思われる。各段積み形 状に执いて，三分力計で得た抗力 $\left(P_{d}\right)$ と揚力 $\left(P_{l}\right)$ より，P= $1 / 2 C \cdot \delta \cdot A \cdot V^{2}$ の式加ら風王力係数を求めて, 抗力係数 $\left(C_{d}\right)$ と揚力係数 $\left(C_{l}\right)$ とした。またモーメントも， $M=1 / 2 \delta \cdot C_{m} \cdot A$ $L V^{2}$ の式からモーメント係数 $\left(C_{m}\right)$ を求めてその結果を図 6 〜 図10に示す。低風速部分では風圧力が小さいため特に 1 段積み では値が乱れているが，風速の高い部分では一定とみなすこと ができる。これらの結果と前報及び日本海上コンテナ協会の結

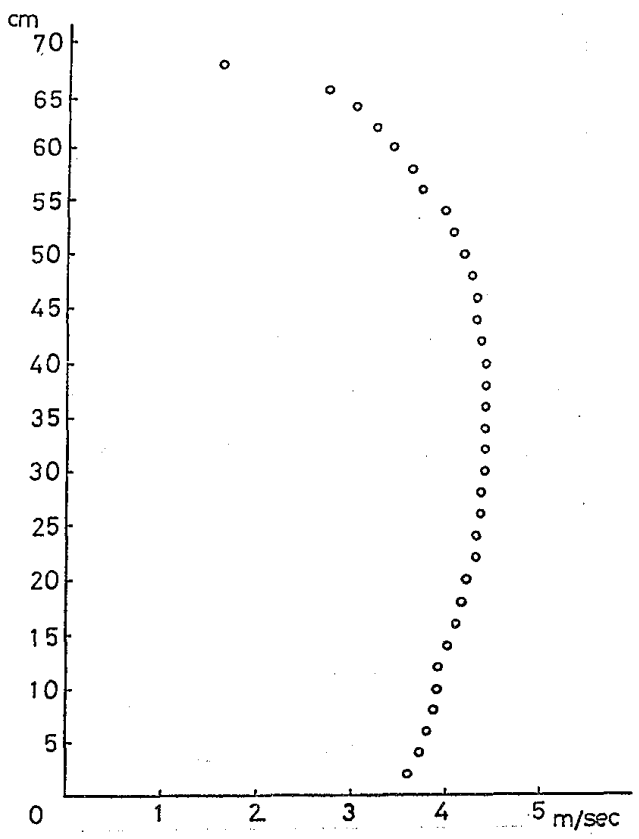

図 5 風速の瑟宣分布

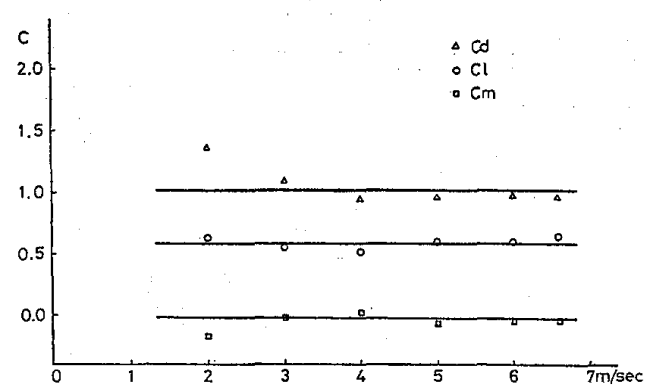

図 61 段積夕風生力係数

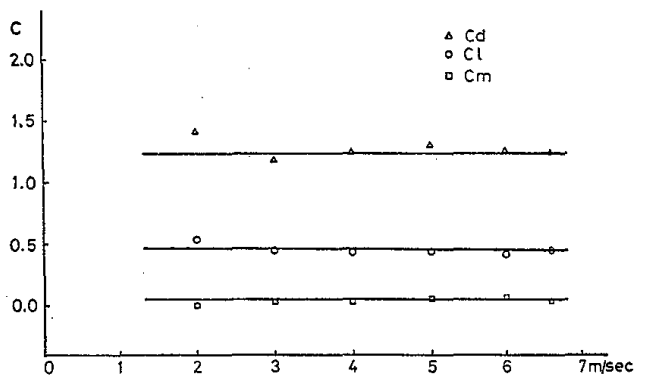

図 72 段積み上段風圧力係数 


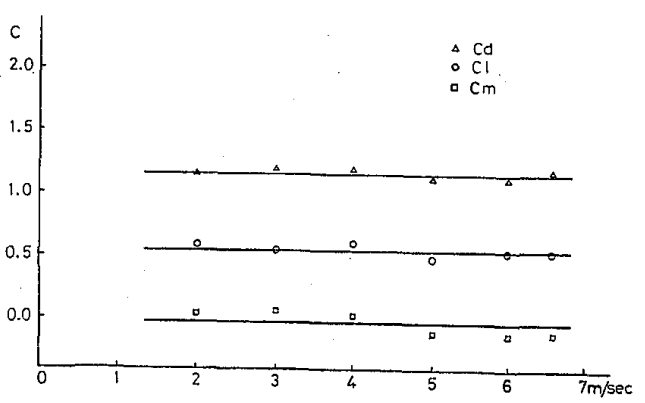

図 82 段積み連結風圧力係数

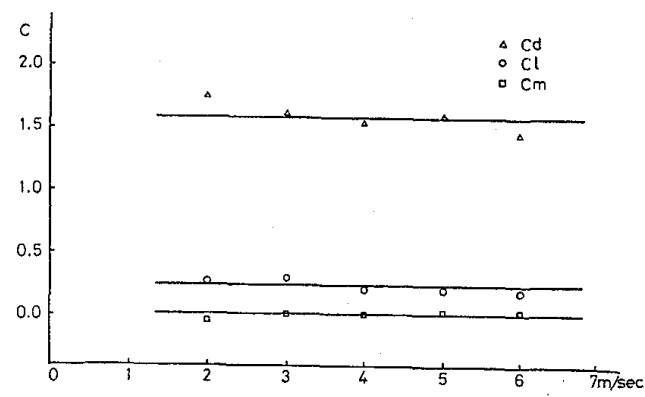

図 93 段積み上段風圧力係数

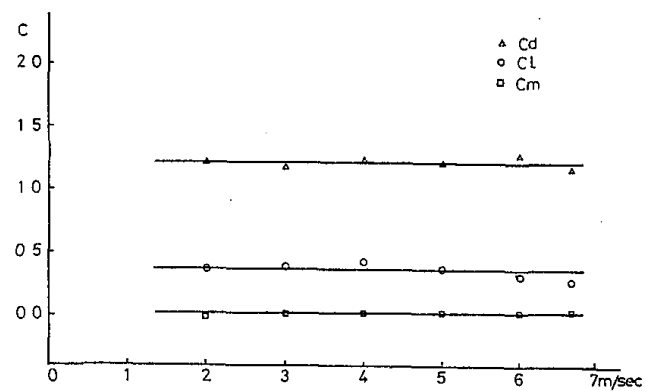

図10 3 段積み連結風生力係数

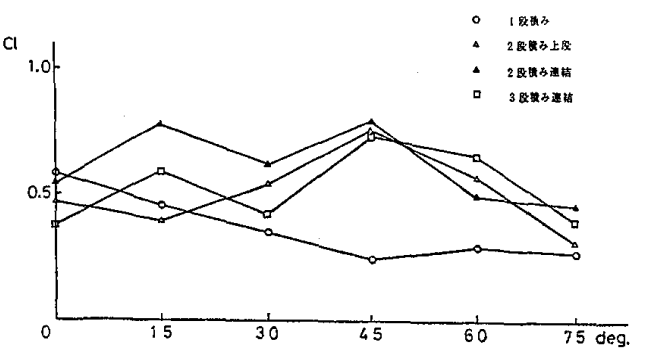

図11風向别揚力係数

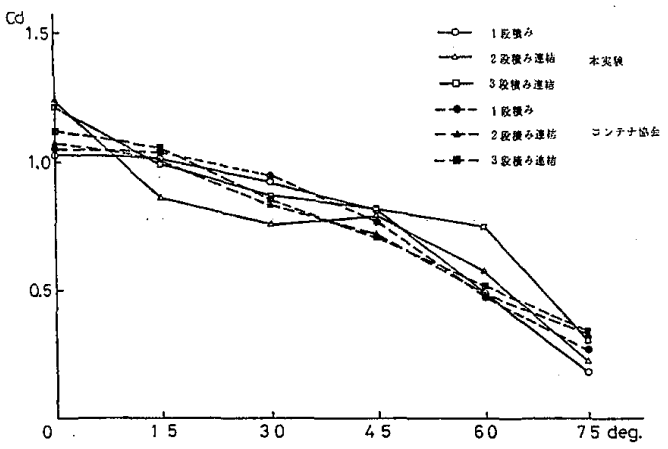

図12 風向別抗力係数
表1 風王力係 数

\begin{tabular}{|c|c|c|c|c|c|}
\hline \multicolumn{2}{|c|}{ 段積み形状 } & $\begin{array}{l}\text { 風厓力 } \\
\text { 係数 }\end{array}$ & 本実験 & 前報 & $\begin{array}{l}\text { コシテナ } \\
\text { 協会 }\end{array}$ \\
\hline \multirow{2}{*}{ 積み } & \multirow[b]{2}{*}{ 田 } & $\mathrm{Cd}$ & 1.025 & 1.001 & 1.051 \\
\hline & & $\mathrm{Cl}$ & 0.581 & 0.631 & 0.179 \\
\hline \multirow{2}{*}{$\begin{array}{c}\text { 2段積み } \\
\text { 上段 }\end{array}$} & \multirow{2}{*}{$\mathbb{Z}$} & $\mathrm{Cd}$ & 1.2 & 11 & 1.071 \\
\hline & & $\mathrm{Cl}$ & 0.465 & 0.727 & 0.027 \\
\hline \multirow{2}{*}{$\begin{array}{c}\text { 2段積み } \\
\text { 連結 }\end{array}$} & \multirow{2}{*}{ 垍 } & $\mathrm{Cd}$ & 1.155 & 1.230 & 1.065 \\
\hline & & $\mathrm{Cl}$ & 0.541 & 0.727 & 0.110 \\
\hline \multirow{2}{*}{$\begin{array}{c}\text { 3段積み } \\
\text { 連結 }\end{array}$} & \multirow{2}{*}{ 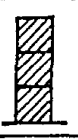 } & $\mathrm{Cd}$ & 1.2 & 1.452 & 1.1 \\
\hline & & $\mathrm{Cl}$ & 365 & 0.862 & 0.0 \\
\hline \multirow{2}{*}{$\begin{array}{c}\text { 3段積み } \\
\text { 上段 }\end{array}$} & \multirow{2}{*}{$\mathbb{E}$} & $\mathrm{Cd}$ & 1.5 & & \\
\hline & & $\mathrm{Cl}$ & 0.24 & & \\
\hline
\end{tabular}

果とを比較して表 1 に示した。コンテナ協会の值は，三菱 長崎研究所の大型風洞に掠いて，六分力天科を使用して求 めたものである。密閉型風洞と開放型風洞の違いがあり， 一般に密閉型の方が風圧汃が実際より大きく，開放型は小 さいといわれているが(3)，その傾向が出ているのか本実験 の值が大きく現われている。特に揚力係数についてはとの 差が大きく検討の余地がある。風间を変化させて得られた 抗力係数と揚力係数を表 2 に示す。これらを図示すると， 本笑験の揚力係数は図11，抗力係数を本契験とコンテナ協 会の結果と合わせて表わすと図12となる。コンデナの滑動 に大きく影響する抗力係数についてみると，峥実験結果と

表 2 風向別風王力係数

\begin{tabular}{|c|c|c|c|c|c|}
\hline \multicolumn{2}{|c|}{ 段積み形状 } & \multirow{2}{*}{\begin{tabular}{|l} 
段税み \\
WIIA \\
\end{tabular}} & \multirow{2}{*}{ 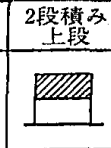 } & \multirow{2}{*}{ 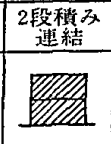 } & \multirow{2}{*}{ 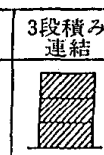 } \\
\hline $\begin{array}{l}\text { 風向 } \\
\text { 角度 }\end{array}$ & 匠力 & & & & \\
\hline \multirow[t]{2}{*}{$0^{\circ}$} & $d$ & 1.025 & 1.235 & 1.155 & 1.21 \\
\hline & $\mathrm{Cl}$ & 581 & 0.465 & 541 & 36 \\
\hline \multirow{2}{*}{$15^{\circ}$} & d & 010 & 0.836 & 677 & 0.98 \\
\hline & $\mathrm{Cl}$ & 95 & 387 & 0.779 & 0.58 \\
\hline \multirow{2}{*}{$30^{\circ}$} & $\mathrm{Cd}$ & 0.922 & 0.738 & 0.654 & 0.86 \\
\hline & $\mathrm{Cl}$ & 344 & 37 & 521 & 40 \\
\hline \multirow{2}{*}{$45^{\circ}$} & $\mathrm{Cd}$ & 0.804 & 0.821 & 0.665 & 0.815 \\
\hline & $\mathrm{Cl}$ & 240 & .751 & 0.785 & 0.72 \\
\hline \multirow{2}{*}{$60^{\circ}$} & $\mathrm{Cd}$ & 0.481 & 0.570 & 0.536 & 0.74 \\
\hline & $\mathrm{Cl}$ & 297 & 0.553 & 0.479 & 0.650 \\
\hline \multirow{2}{*}{$75^{\circ}$} & $\mathrm{Cd}$ & 173 & 0.220 & 0.197 & 0.29 \\
\hline & $\mathrm{Cl}$ & 268 & 296 & 0.460 & 0.39 \\
\hline \multirow[t]{2}{*}{$90^{\circ}$} & $\mathrm{Cd}$ & 65 & 94 & 0.085 & 0.10 \\
\hline & $\mathrm{Cl}$ & 225 & 225 & 0.311 & 0.38 \\
\hline
\end{tabular}


も同じ傾向を示している。これによると風向角が大きくなると $C_{d}$ は二次曲線にとって減少し， $\theta=0$ 度の時が最 も滑動し易く，角度が大きくなる程滑動開始風速も二次曲線的に大きくなる。シミュレーションを行ら予備実験 で単体の場合と，5個のコンテナを横に並べた場合について角度を変えて滑動開始風速を測定した結果, $40 \mathrm{f} t$ コ ンテナの縮尺 1/40 のものを单体で行った時は図13で，20f't コンテナの縮尺 1/40のものを5個横に並べた時 を 5 個並列として図14k示す。この結果をみると最も滑動し易いのは15度から30度付近の風を受けた時でこの付 近で最小值を取る二次曲線の形であるがその変化率は小さく，図12の抗力係数から試算した滑動開始風速より低 い風速で滑動し，角度の增加とともにその差は大きくなる。また図13と図14は20f't と40f't の違いがあるが， ブロック化すると滑動開始風速も大きくなっている。以上のことを考え合わすと，本実験ではローリングモーメ ントを測定して高さ方向の風圧力中心位置は求まるが，ヨーイングモーメントを測定して長さ力何の風圧力中心 位置を求める必要がある。ブロック化については前報でも少し触れた縦横比による抗力係数の変化を知る必要が ある。以上については今後の課題としたい。

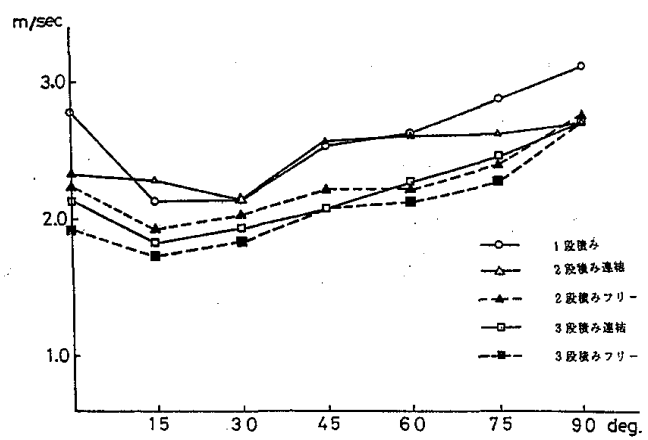

図13 通向别滑動開始屈速 (40 f't, $1 / 40$ 単体)

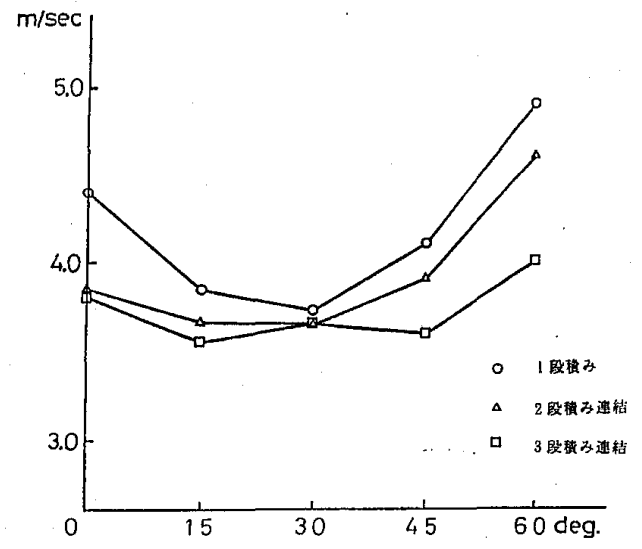

図14 風向別滑動開始風速 （20 f't, 1/40，5 個並列）

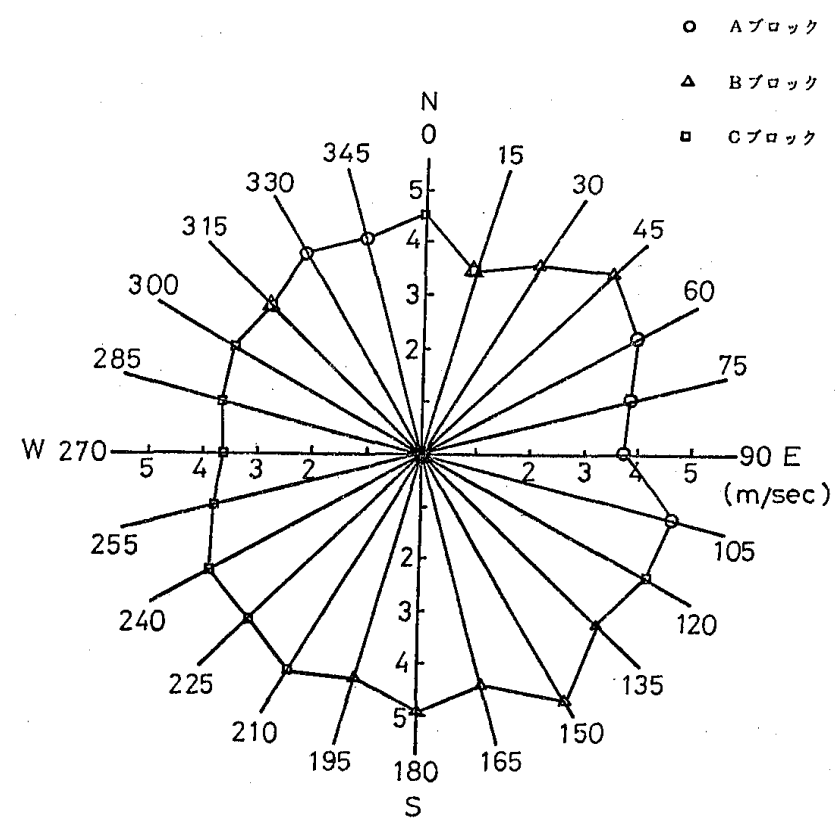

図15 1 段積みシミニレーション

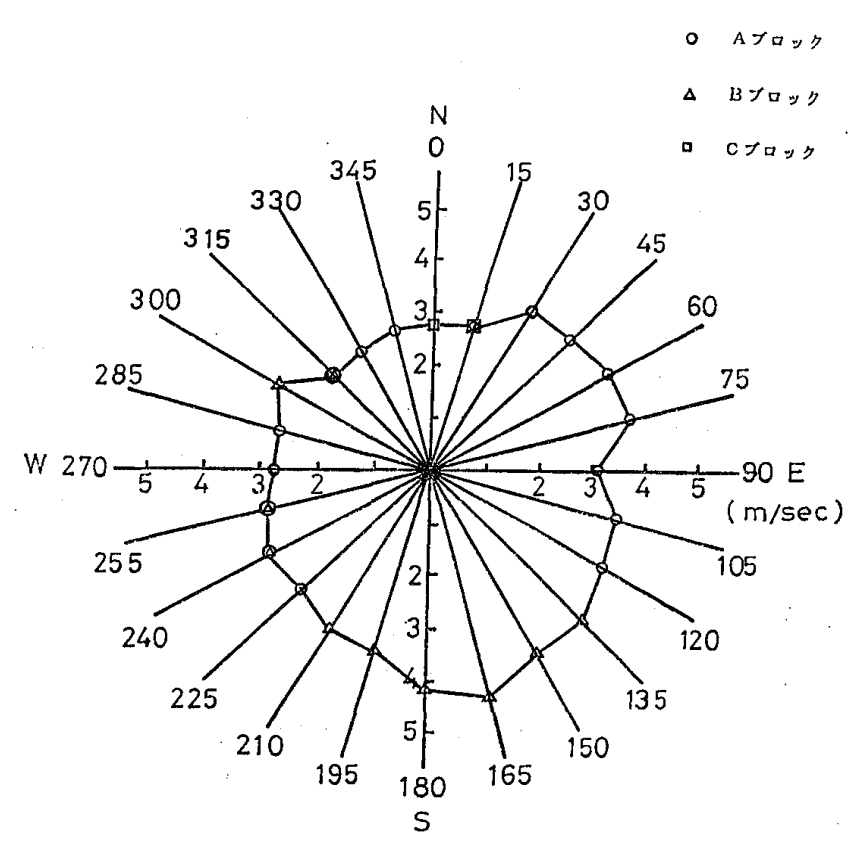

図16 3 段積みシミュレーション 


\section{2 ヤード模型赛験}

1 段積み及び 3 段積みフリーの場合の全風向の滑動開始風速を同じスケールで図15 と図16に示す。図 4 に示し た P C一11ヤードのレイアウトから，ニンテナが南北方向に配列されているので東西の風に対して滑動し易いの は容易に想像できる。ここでる先に述べたシミュレーションの予備実験の結果と同様に，東西の軸を中心にして 北仿度から30度，南に15度から30度の範囲で滑動し易いことがかかる。風向と滑動開始場所をみてゆくと，東 等りの風では 1 段，3 段ともAブロックの東端が滑動する。西寄りの風では1段積みではCブロック， 3 段積み では AとBブロックが滑動する。1 段積みの場合風の前面のBブロックより後面のCブロックが滑動するのは， Bブロックで乱された流れがゲートやコントロールオフィスの影響を受けてCブロックの西端が滑動すると思わ れる。北寄りの風では $\mathrm{A}$ そ Bブロックが滑動するが，真北の風の場合 1 段，3 段とも後面のCブロックが低風速 で滑動している。これも建造物の影響と思われるが，ヤードの現場での説明でもゲート付近のコンテナがよく滑 動するとのことであった。南寄りの風ではほとんどBブロックが滑動するが，滑動開始風速が大きいのは，ヤー ドの南側认道路を隔てて $7 \sim 8 \mathrm{~m}$ の防波堤があるためである。3 段積みの場合恃北の風から反時計回りに南西の 風の範囲にかけてAとBブロックが非常に滑動し易いといえる。上記の結果をもとにして実物換算をしなければ

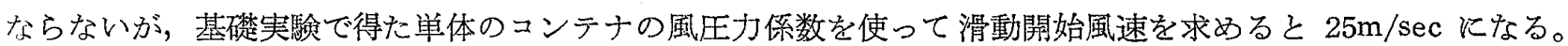
前述の様に害際にはもっと低い風速で滑動し，上の風速值で対応することは危険である。供試模型と実物との相 似条件を比較すると，縮尺 $1 / 40$ であるから模型重量＝実物重量 $\times 1 / 40^{3}$ で供試模型重量が $0.06 \mathrm{~kg}$ であるから

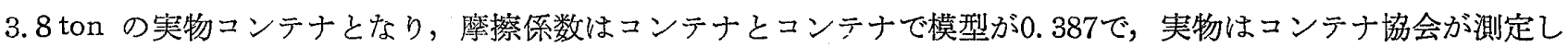

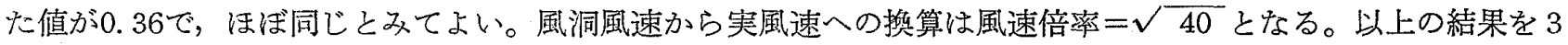
段積みシミュレーションに適用すると図16の風速は実物換算では, $3 \mathrm{~m} / \mathrm{sec} か ゙ ~ 19 \mathrm{~m} / \mathrm{sec}, 4 \mathrm{~m} / \mathrm{sec}$ が $25 \mathrm{~m} / \mathrm{sec}$ とな る。コンテナ協会の報告の中に各ターミナルへのアンケート調查で $20 \mathrm{~m} / \mathrm{sec}$ 未満で滑動した例がいくつかある。

\section{4. むす び}

現在コンテナ・ターミナルに拉いて，主に台風の接近の恐れのある場合，ヤード全域にわたって以下のような 派散防止詨策が行われている。

(1) クシの菊状をならして出来るた゚けブロック化する。

(2) コンテナを連結する。

(3) 空コンテナの上に実入りのコンテナを乗せる。

等であるが，いずれる大变な作業である。しかし冬の季節風や春一番の突風でも飛散の贷険は十分にあり，現に 飛散の例もこの場合が多い。一連の基礎实験とシミュレーションの結果，明らがなったことは以下のと括りで ある。

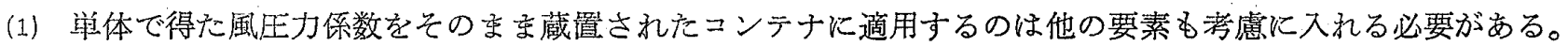

(2) コンテナの長手方向に対して15度から30度の範国の風向の時が滑動し易い。

(3) シミュレーションの結果をもとに，台風の進路によってより万全な飛散防止の対策をとることができ，無

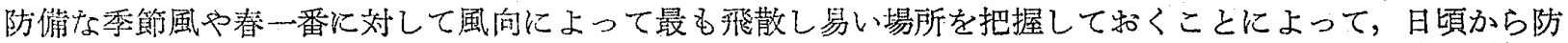
此対策が出来る。同時汇地理的条件や建造物の影響も把握しておくことが出来る。

\section{参考 文 献}

（1）本田啓之輻・堀富士男：コンテナの耐風に関する檔型実験，日本航海学会論文集，63号，昭和55年 8 月

（2）日本海上コンテナ協会：風洞実験によるコンテナの挙動調查報告書，昭和56年 3 月

（3）石崎潑雄：耐風工学, p. 123 , 朝倉畫店, 昭和 52 年

\section{質 疑 応 答}

三木 䙉彦：

(1) ストラドルキャリア方式とトランステナー方式でのコンテナ藏置形驡が大きく相違します。風洞寒験結果 
を両方式に適用する場合の留意点等について和聞きしたい。

(2) 今後の研究の方向例兄ば防災対策についてお聞きしたい。

\section{堀 富士男：}

(1) 密着して蔵置できるトランステナー方式に比ベストラドル方式の方が飛散の例も多いので本実験では後者 のみを考光て行って括ります。トランステナー方式ではブロック化されて呿りますので骾しにくいと思い ますが今後の課題と致します。

（2）防災対策まで諭じなければならないと思って拉りますが，人手と費用のかからない方法となりますと難し い問題です。防風ネットの実䟻も行って招りますが現実問題としてコンテナ・ターミナルに設置出来るかど らか疑問ですし，大型台風となれば現在の飛散防止対策を取ることになると思います。

久々宮 久：他機関の測得値との比較で特に揚力係数 $C_{l}$ に桁違いの差が見られます。無次元化法の䢙いがあるの ではありませんか，御検討叔がいます。

堀 富士男：無次元化の方法は同じようです。確か炏差が大きいのですが，考光られますことは，境界層の厚さ に対する模型の大きさがコンテナ協会の場合 $30 \mathrm{~mm}$ の厚さに対して縮尺 $1 / 10$ で $20 \mathrm{f} t$ コンテナの模型の高 さが $26 \mathrm{~cm}$ です。本奏験では $12 \mathrm{~cm}$ で，境界層の厚さは測定して和りません。これは抗力係数より揚力係数 に影響するそうです。もう一点は三分力計を模型の中に組み込んでコンテナの底を閉じるようにしたのですが 多少風が流れ込んだ可能性もあるかもしれません。しかし一般化築関係の資料をみますと立法体の揚力係数 は 0.5 とされて招ります。 